\title{
ELLJ
}

\section{Economic dependence and parental protection: A comparative analysis of Austrian and Slovenian labour and social security rights of economically dependent self-employed parents}

European Labour Law Journal 2022, Vol. 13(I) 86-107 (C) The Author(s) 2021

(c) (1)

Article reuse guidelines: sagepub.com/journals-permissions DOI: I0.II77/203|95252। I060362 journals.sagepub.com/home/ell @SAGE

\author{
Sara Bagari \\ Department of Labour Law and Social Security Law, Faculty of Law, University of \\ Ljubljana, Ljubljana, Slovenia
}

\section{Maria Sagmeister}

Research Platform GAIN, Faculty of Law, University of Vienna, Wien, Austria

\begin{abstract}
Taking parental protection rights as a clear-cut field of study, this article argues that there are significant protection gaps in the social rights and employment protection of the economically dependent self-employed. Their exclusion from employment protection can be justified as far as the protective purpose is tied to the personal subordination of the employee relationship. However, certain vulnerabilities arise not from personal, but from economic dependency, whereas the changing labour market and the growing area of precarious self-employment must be considered. Comparing the rights of working parents in Slovenia and Austria, we distinguish between employees and economically dependent self-employed persons in this specific area and point to challenges for the wider field of labour and social rights. The purposes of parental protection rights are diverse; they include health protection, guarantee social security and serve equal treatment purposes. Therefore, they represent an ideal field to discuss arguments regarding the inclusion or exclusion of the economically dependent self-employed into different protective frameworks.
\end{abstract}

\section{Keywords}

Parental protection, maternity protection, maternity leave, parental leave, economically dependent self-employed, precarity, protection from dismissal, parental benefit, maternity benefit, health protection, freier Dienstvertrag, social protection, employment protection

\section{Corresponding author:}

Maria Sagmeister, Research Platform GAIN - Gender: Ambivalent In_Visibilities, Faculty of Law, University of Vienna,Vienna, Austria.

E-mail: maria.sagmeister@univie.ac.at 


\section{Introduction: Why focus on the parental protection of economically dependent persons?}

Labour law protection for working parents allows them to take a break from work to devote themselves to their family responsibilities and protects them against dismissal during that time. Maternity protection specifically recognises the fact that potential dismissal poses a risk to the physical and mental well-being of pregnant workers and workers who have recently given birth or are breastfeeding. This includes the risk of encouraging workers to voluntarily terminate their pregnancies, ${ }^{1}$ or put their family planning on hold due to an unsecure working environment. But more and more workers are not - or not fully - included in these protective schemes.

As parental protection is granted mainly to workers engaged in the employment relationship based on an employment contract, people working on other legal bases, such as the self-employed, do not enjoy this protection. Even where some entitlements exist, the fear of losing clients might hinder parents from taking (full) advantage of parental leave, as in the case of economically dependent self-employed persons, in whose case the loss of a main client exposes them to risks very similar to those mentioned above.

While self-employment covers a broad spectrum of social and economic situations and cannot be approached in a uniform way, ${ }^{2}$ numerous studies show that such workers face challenges and lack protection in different areas, such as labour and social protection, working conditions and collective representation. ${ }^{3}$ Their protection has therefore been a concern for individual countries, as well as for the EU, for several years. ${ }^{4}$

This article examines the situation of a specific category within self-employment: the economically dependent self-employed (hereinafter, the EDS). This group is particularly vulnerable due to the economic dependency on one (main) client, and therefore requires special protection. There is no clear-cut definition of the EDS. However, drawing from different (but similar) definitions in the

1. See, for example, Council Directive 2010/18/EU of 8 March 2010 implementing the revised Framework Agreement on parental leave concluded by BUSINESSEUROPE, UEAPME, CEEP and ETUC and repealing Directive 96/34/EC, OJ L 68, 18. 3. 2010.

2. Rosioru, Felicia, 'Legal Acknowledgement of the Category of Economically Dependent Workers', in: European Labour Law Journal 2014/5, 279-305 (284); furthermore, definitions of the self-employed also vary in the EU, see Eurofound, 'Exploring self-employment in the European Union', Publications Office of the European Union, Luxembourg 2017, 48$50(37-46)$.

3. E.g. Eichhorst, Werner et al., 'Social protection rights of economically dependent self-employed workers', Study for the EMPL Committee, Brussels 2013; Spasova, Slavina et al., 'Access to social protection for people working on nonstandard contracts and as self-employed in Europe. A study of national policies', European Social Policy Network (ESPN), Brussels 2017; Matsaganis, Manos et al., Non-standard employment and access to social security benefits, Luxembourg 2015; Broughton, Andrea et al., 'Precarious Employment in Europe: Patterns, Trends and Policy Strategies', Study for the EMPL Committee, Brussels 2016; Eichhorst, Werner/Tobsch, Verena, 'Risk of precariousness: Results from European Working Conditions Survey 2010 and 2015: In-depth analysis for the EMPL Committee', Brussels 2017; Williams, Colin C./Horodnic, Alexandra, Dependent Self-Employment, Theory, Practice and Policy, Cheltenham/Northampton 2019.

4. See, for example, Council Recommendation 2003/134/EC of 18 February 2003 concerning the improvement of the protection of the health and safety at work of self-employed workers (OJ L 53, 28. 2. 2003); Directive 2010/41/EU of the European Parliament and of the Council of 7 July 2010 on the application of the principle of equal treatment between men and women engaged in an activity in a self-employed capacity and repealing Council Directive 86/613/EEC (OJ L 180, 15. 7. 2010), Council Recommendation of 8 November 2019 on access to social protection for workers and the self-employed, (OJ L 387, 15. 11. 2019). 
literature, ${ }^{5}$ the term 'the EDS', as used in this article, refers to the self-employed who (1) do not employ other persons ${ }^{6}$ and (2) depend on one client for all or most of their income (i.e. being economically dependent on this client). In this respect organisational dependency, as one of the variables chosen by the Eurostat to define the economically dependent self-employed, ${ }^{7}$ is not considered to be a defining element, as it indicates bogus self-employment.

A group report led by Supiot in 2000 describes the EDS as 'workers who cannot be described as employees, and yet are economically dependent on a single client.' One of the report's main findings is that, due to their economic dependency, this group should be entitled to certain social (security and labour) rights. Since then, the perpetual challenge facing labour and social law is if, how and to what extent the scope of protective standards should be extended to the EDS. Furthermore, they are currently in the spotlight due to their growing number and a recognised need to ensure they are better protected, both at national and European level. ${ }^{8}$

There are many contributions within labour law scholarship that address the question of the personal scope of labour law and whether protection should be granted only to employees, or whether other categories of workers, such as the EDS, should be included. ${ }^{9}$ For example, Rosioru argues that fundamental (labour) rights should be attached to the notion of risk. Similarly, Fusco suggests rethinking the allocation criteria of labour protection and adopting 'economic subordination' as the main criterion. ${ }^{10}$ In recent years, the issue of the EDS has become one of the most popular topics in labour law literature. ${ }^{11}$ However, the focus to date has not been on their parental protection rights. There is an apparent lack of literature focusing on the importance of parental protection for the selfemployed, much less for the EDS. As pointed out by Chieregato, despite the rise in non-standard employment (including self-employment), limited attention has been paid to inequalities in

5. See, for example, Pedersini, Roberto, “Economically dependent workers”, employment law and industrial relations', Eurofounds Report 13 June 2002, www.eurofound.europa.eu/publications/report/2002/economically-dependent-workers-employment-law-andindustrial-relations (last visited 10 June 2021); ILO, Non-standard employment around the world: Understanding challenges, shaping prospects, Geneva 2016; Williams/Horodnic, Dependent Self-Employment, 2019; Eichhorst et al., Social protection rights, 2013; Rosioru, European Labour Law Journal 2014/5(3-4).

6. On average, more than two-thirds of all self-employed workers in the EU do not have employees (solo self-employed) Eurostat, Self-employment statistics, The 2017 Labour Force Survey (LFS) ad-hoc module, 2018, https://ec.europa.eu/ eurostat/statistics-explained/index.php/Self-employment_statistics\#cite_note-2 (last visited 10 June 2021).

7. Eurostat, Self-employment statistics 2018.

8. Rosioru, European Labour Law Journal 2014/5(3-4); ILO, Non-standard employment 2016; Williams, Colin C./ Lapeyre, Frédérinc, Dependent self-employment: Trends, challenges and policy responses in the EU', ILO Working Paper No. 228, Geneva 2017; Williams/Horodnic, Dependent Self-Employment 2019; Domadenik, Polona et al., 'Empirična analiza prekarnosti na trgu dela v Sloveniji' (Empirical analysis of precariousness on the Slovenian labour market), in: Kresal Šoltes, Katarina /Strban, Grega /Domadenik, Polona (eds), Prekarno delo: multidisciplinarna analiza (Precarious work: multidisciplinary analysis) Ljubljana 2020, 263-280.

9. See, for example, Davidov, Guy/Langille, Brian (eds), Boundaries and Frontiers of Labour Law, London, 2006; Freedland, 'Application of labour and employment law beyond the contract of employment', International Labour Review, 2007/146, 3-20 (4); Waas, Bernd/Van Voss, Guus Heerma (eds.), Restatement of Labour Law in Europe. Volume I: The Concept of Employee, Oxford 2017 (Web); Hendrickx, Frank, 'Regulating new ways of working: From the new "wow" to the new "how", European Labour Law Journal 2018/9, 195-205.

10. Fusco, Federico, 'Rethinking the allocation criteria of the labour law rights and protections: A risk-based approach', European Labour Law Journal 2020/11(2), 131-141 (140).

11. Some examples are Rosioru, European Labour Law Journal 2014/5(3-4); Gyulavári, Tamás, 'Trap of the Past: Why Economically Dependent Work is Not Regulated in the Member States of Eastern Europe', European Labour Law Journal, 2014/5(3-4), 267-278; Williams/Lapeyre, Dependent self-employment 2017; Williams/Horodnic, Dependent Self-Employment 2019. 
accessing and using work-life-balance (WLB) measures - parental protection rights being an important part of them - across occupational levels or employment contracts. ${ }^{12}$

In addition, in the field of social security, most studies take a general approach to the social protection of the self-employed or the EDS, ${ }^{13}$ without specific emphasis on parenthood-related benefits. We suggest looking at parental protection of the EDS more closely, as the risk of not being covered by parental benefits, especially by maternity and paternity benefits, is particularly high among the self-employed. ${ }^{14}$

We hope to contribute to the debate on the challenges concerning the social and labour law protection of the EDS, for one, by adding an in-depth analysis of this particular field of law to the picture, and further, by stressing the importance of taking an intersectional approach to labour and social protection. Besides their specific socio-economic position, the experiences and opportunities of the EDS are shaped by other factors, such as their gender. As it is still mainly women who engage in unpaid care work in the home, not taking parental protection into consideration means not taking their lived experiences into consideration. In acknowledging the relationship between work and social reproduction, gender offers a lens to more fully appreciate the possibilities of disrupting and reshaping work in ways that 'deliver not precariousness, but rather arrangements which genuinely enhance the opportunities for workers to engage in decent work.' 15

Parental protection rights are important measures to enable gender equality in the workplace and beyond. While much effort has been put into fostering a more equal distribution of unpaid care work between women and men in recent decades, particularly at the European level, their effectiveness is limited as they do not reach into all realms of work to the same extent. The Directive (EU) 2019/1158 on Work-Life Balance for Parents and Carers ${ }^{16}$ takes atypical forms of employment into consideration, but the self-employed are still not included in the scope. A large majority of female workers worldwide are not adequately protected in case of maternity, and amongst the groups which are more frequently excluded from protection in law and in practice, are the self-employed. ${ }^{17}$ The risk of not being adequately covered by financial parental benefits has also been recognised as being the highest among the self-employed. According to Matsaganis et al., in 2014 in the EU as a whole, on average around $46 \%$ of self-employed women were at risk of not being eligible for maternity benefits. ${ }^{18}$ Furthermore, the remuneration for maternity leave for the self-employed is often lower than for employees, and in some countries is paid at a flat rate level for those in selfemployment, while in the case of employees, it usually reflects the level of the previous income. ${ }^{19}$ According to the European Institute for Gender Equality, seven Member States do not offer parental leave to the self-employed, while in other countries, self-employed parents are entitled to parental leave, but there are still differences in the requirements concerning the duration

12. Chieregato, Elisa, 'A Work-Life Balance For All? Assessing the Inclusiveness of EU Directive 2019/1158', International Journal of Comparative Labour Law and Industrial Relations 2020/36(I), 59-80 (72).

13. Eichhorst et al., Social protection rights 2013; Matsaganis et al., Non-standard employment 2015; Spasova et al., Access to social protection 2017, 41.

14. Matsaganis et al., Non-standard employment 2015,16.

15. Conaghan, Joanne, 'Time to Dream? Flexibility, Families and the Regulation of Working Time', in: Fudge, Judy/ Owens, Rosemary (eds), Precarious work, women and the new economy: the challenge to legal norms, Oxford 2006, 101-129 (106).

16. OJ L 188, 12. 7. 2019.

17. ILO, Maternity and Paternity at Work, Law and practice across the world, Geneva 2014, xiv.

18. Matsaganis et al., Non-standard employment 2015, 33.

19. Eurofound, Exploring self-employment 2017, 48-50. 
of self-employment and the sector in which self-employed parents work. ${ }^{20}$ Further, within the group of working mothers, the 'fact that dependent self-employed workers do not equally benefit from social protection, including maternity leave payment, poses a challenge to the principle of equity among working women. Indeed, they are discriminated over women in regular dependent employment, given that they often only have access to maternity leave payments at a minimum level. $^{21}$

In this article, we address this shortcoming and address the following research question: Why and to what extent should the EDS benefit from parental protection?

We suggest a comprehensive approach to parental protection as a whole set of rights, covering social security as well as employment protection rights, such as the right to protection against dismissal. This approach recognises that the actual uptake of leave entitlements depends strongly on the availability of financial support and job protection measures during absence from work.

Therefore, in this article, the term 'parental protection rights' covers (1) employment protection rights, including the protection of the employment status while on leave, protection against dismissal, and rights aiming to ensure the health and safety of pregnant workers and workers who have recently given birth. Further, 'parental protection rights' include the (2) social security rights that concern parents and their children. In general, the purpose of social security is the protection that society provides in the event of the materialisation of a social risk that results in a loss or a significant reduction of income or an increase in costs through a process of broader or narrower social solidarity. ${ }^{22}$ As parenthood is presumed to cause temporary work incapacity (due to childbirth and childcare), it calls for income replacement benefits. Moreover, having a family increases living costs, and cost-compensating benefits are also granted.

An important factor in respect of the scope of those rights is the employment status. Although there are national differences concerning the (partial) inclusion of the (economically dependent) self-employed across the EU, one of the main factors for eligibility is the distinction between the employee and the self-employed. ${ }^{23}$

To address this issue, we have analysed and compared the legal status and parental rights of the EDS in two neighbouring European countries, Slovenia and Austria. Comparison of these two countries is relevant for many reasons. Firstly, they both represent developed continental European countries with comparable legal traditions and socio-economic contexts. Regarding labour law, they share the traditional binary system, consisting of employment contracts and civil law contracts. Secondly, because they are neighbouring countries, their comparison is highly relevant from a practical point of view, due to the free movement of workers and issues around social security coordination. Thirdly, their comparison is instructive at a structural level due to the fact that both states have legally recognised the EDS, albeit in different forms and to different extents.

The article is structured as follows. After giving a brief overview of the legal definition of the EDS with reference to international frameworks, the definitions and legal status of the EDS in Austria and Slovenia are analysed and compared. This lays the groundwork for an overview of parental protection rights in both countries, focusing on the difference between employees, the

20. European Institute for Gender Equality, Eligibility for parental leave in EU Member States, Luxembourg $2020,13$.

21. Eichhorst et al., Social protection rights 2013, 97.

22. Strban, Grega/Bagari, Sara, 'Reliance on long-term care as a "new” social risk in national and EU law', in: Przegląd Prawa i Administracji Tom 2020/123, 98.

23. European Institute for Gender Equality, Eligibility 2020, 12. 
traditional self-employed and the EDS. This analysis is accompanied by a comparison highlighting the advantages and disadvantages of the national frameworks and a discussion on what scope of parental protection should be granted to the economically dependent self-employed. We conclude with a reflection on common problems and possible solutions.

\section{The economically dependent self-employed: definition and challenges}

The first question that must be addressed, is about the scope: Who are the EDS, and why do they deserve our attention?

The EDS fall between the concepts of employment and self-employment. They do not fit into the traditional definition of employees, mainly because of a lack of personal dependence, which is still considered to be the main element of the employment relationship, ${ }^{24}$ and therefore they do not enjoy the same level of protection as employees. However, they cannot be identified as genuinely (independent) self-employed either, ${ }^{25}$ since they receive their income (mainly) from one client or a small number of clients, which makes them economically dependent on them. According to the European Economic and Social Committee, profound economic and social changes affect the nature of self-employment, moving it beyond the traditional notion of independent work that is recognised in the countries of the European Union. ${ }^{26}$

The EDS are often referred to as an intermediate category. Formally, they are self-employed and perform services for clients under a contract different to an employment contract. However, they are also economically dependent on a single client for all or most of their income, and therefore, ${ }^{27}$ their situation can be very close to the situation of employees. This is particularly true where there is no clear organisational separation between the EDS and the client, and they perform the same tasks as employees of the client.

At this point, a distinction must be made between the EDS and a disguised employment relationship, also known as bogus self-employment. ${ }^{28}$ According to the International Labour Organisation (ILO), disguised employment gives 'an appearance that is different from the underlying reality, with the intention of nullifying or attenuating the protection afforded by law'. ${ }^{29}$ In the case of the bogus self-employed, it consists of disguising the nature of the relationship by engaging the

24. ILO, Regulating the employment relationship in Europe: a guide to Recommendation No. 198, Geneva 2013; Governance and Tripartism Department. For Austria, see Rebhahn, Robert in Neumayr, Matthias/ Reissner, Gert-Peter, ZellKomm ${ }^{3}$, § 1151 ABGB (1.1.2018, rdb.at) para 80; for Slovenia, see Vodovnik, Zvone/ Korpič-Horvat, Etelka, Labour Law in Slovenia ${ }^{2}$, Alphen aan den Rijn 2015.

25. To be classified as an independent self-employed person, an individual should work as an autonomous subcontractor who owns his/her means of production and works independently in order to accumulate capital and serve several clients; Thörnquist, Annette, 'False Self-Employment and Other Precarious Forms of Employment in the "Grey Area" of the Labour Market', International Journal of Comparative Labour Law and Industrial Relations 2015/ 31(4), 411-429.

26. Opinion of the European Economic and Social Committee (2011) 'New trends in self-employed work: the specific case of economically dependent self-employed work' (own-initiative opinion), OJ $2011 \mathrm{C} \mathrm{18,} 44$.

27. Pedersini, Eurofounds Report 2002; ILO, Non-standard employment 2016.

28. A distinction is often not clear; on this, see Williams/Horodnic, Dependent Self-Employment 2019; Bagari, Sara, 'The European Pillar of Social Rights: An EU-level Response to the Social Protection of the (Economically) Dependent Self-Employed?' in: Zbornik znanstvenih razprav 2020/1 (Special Issue: Perspectives on the European Pillar of Social Rights), 101-118.

29. ILO, 'Disguised employment / Dependent self-employment', www.ilo.org/global/topics/non-standard-employment/ WCMS_534833/lang-en/index.htm (last visited 10 June 2021). 
worker in a civil, commercial or cooperative contract instead of an employment contract, while directing and supervising the working activity in a manner incompatible with the independent status of self-employment. In this way, the worker is deliberately misclassified as an independent, self-employed person when in reality, he or she is in a subordinate employment relationship. ${ }^{30}$ Since the self-employed in the disguised employment relationship should legally be considered as employees, both in Austria and Slovenia, they are not discussed further in this article. Our focus lies on the EDS, who receive most of their income from one client while still having authority over working methods, work content, time and place.

Economically dependent work is often the consequence of an employers' strategy to reduce costs and to evade labour regulations, with the aim of excluding workers from the protection legally granted to employees. ${ }^{31}$ In many cases, economically dependent self-employment is not a voluntary decision, but one forced by external factors such as the outsourcing of production or restructuring of the company with the resulting redundancies. ${ }^{32}$ The EDS can be found in many different sectors such as hospitality businesses, catering, media, editing, teaching and training, marketing, telemarketing, advertising, entertainment, administration, accounting and social services, but also in more traditional sectors, such as transport, the building industry and domestic work. ${ }^{33}$ Using the definition of the EDS chosen in the context of the 2017 module, Eurostat findings show that the dependent self-employed are mainly present in the construction sector and in the human health and social work activities, followed by professional, scientific and technical activities, transportation and storage, education and information and communication. ${ }^{34}$

According to Eurofound, the $\operatorname{EDS}^{35}$ have lower levels of job quality, less autonomy over their work $^{36}$ and are generally in a more precarious situation with lower levels of income and job security than other groups of self-employed persons. ${ }^{37}$ The 2017 Labour Force Survey (LFS) ad hoc module on self-employment also showed that the percentage of self-employed persons who are able to influence both the content and order of tasks is the lowest among self-employed with one client or one dominant client. They rely heavily on the functioning of work relations with their main client, due to their economic dependence, and they are exposed to increased work-related insecurities. They do not benefit from maternity leave payments to the same extent as employed women and often have access to maternity leave payments at a minimum level only. ${ }^{38}$ As a response to their economic vulnerability, some countries already provide the EDS with (limited) social protection ${ }^{39}$ and labour law rights. In those countries, economic dependence becomes the basis for specific labour and social law rights not granted to other types of self-employed workers but less extensive

30. Rosioru, European Labour Law Journal 2014/5(3-4), 286; ILO (2016), 9.

31. Rosioru, European Labour Law Journal 2014/5(3-4), 284-285.

32. Opinion of the European Economic and Social Committee (2011), 2.

33. Rosioru, European Labour Law Journal 2014/5(3-4), 287 with reference to Pedersini, Eurofounds Report 2002.

34. Eurostat, Self-employment statistics 2018.

35. In the report, economically dependent self-employed persons who rely on a very small number of clients are classified as 'vulnerable' (see Eurofound, Exploring self-employment 2017, 1).

36. The 2017 Labour Force Survey (LFS) ad hoc module on self-employment also showed that the percentage of selfemployed persons who are able to influence both the content and order of tasks is the lowest among self-employed with one client or one dominant client (Eurostat, Self-employment statistics 2018).

37. Eurofound, Exploring self-employment 2017, 18.

38. Eichhorst et al., Social protection rights 2013, 97.

39. It could be argued that those who carry out their professional activities in economic dependency are more affected by social risks than those who are independently self-employed. 
than the rights accorded to employees. ${ }^{40}$ Although personal dependency is the main factor in determining the employee status, economic dependency and the imbalance of bargaining power legitimize, therefore, protective labour and social laws. ${ }^{41}$ In other words, dependency, albeit economic not legal, justifies (limited) labour and social protection.

Although the majority of workers in Slovenia as well as in Austria still work in the employment relationship (either standard or non-standard), ${ }^{42}$ self-employed persons represent an important part of both labour markets. The share of self-employed people in the total employment market is around $11 \%$ in Austria and $12 \%$ in Slovenia, while the EU-27 average is around $14 \% .{ }^{43}$ In $2017,18.2 \%$ of self-employed people in the EU-28 reported having only one client or a dominant client. The percentage of the self-employed who had only one client or one dominant client is higher than EU average in both countries, as $19.7 \%$ of the self-employed in Austria and $21 \%$ of the self-employed in Slovenia depend on one major client. ${ }^{44}$

\section{Legal recognition of the economically dependent self-employed in Slovenia}

As its Austrian counterpart, Slovenian labour law mainly protects employees, that is, those persons working on the basis of an employment relationship. ${ }^{45}$ However, the notion of the economically dependent person was introduced in Slovenia by the Employment Relationship Act 2013 (Zakon o delovnih razmerjih; ZDR-1), ${ }^{46}$ which defines economic dependence as a factor for the recognition of limited labour law protection for the self-employed.

According to Article 213 of ZDR-1, an economically dependent person is a self-employed person who, on the basis of a civil law contract, personally, for remuneration, independently, and for a longer period of time, performs work in circumstances of economic dependence and does not employ workers. Therefore, the term 'economically dependent person' used in the ZDR-1 is consistent with the definition of the EDS used in this article.

The elements that can be deduced from this definition are the following: self-employment; working on the basis of a civil law contract; the personal, independent, and long-term performance of work; economic dependence; and not employing employees (i.e., solo self-employment).

The term 'self-employed' is not defined in ZDR-1, but it is defined by different laws in the field of social security and occupational health and safety. There, the self-employed are defined as persons who independently perform gainful or other permitted activity in the Republic of Slovenia. Economic dependency means that a person obtains at least $80 \%$ of his or her annual income from the same contracting entity/client, ${ }^{47}$ although the self-employed may also receive a certain share of income (up to $20 \%$ ) from other clients. However, to be entitled to the limited

40. Opinion of the European Economic and Social Committee (2011), 44.

41. Risak, Martin/Rebhahn, Robert, 'The Concept of "Employee”: The Position in Austria', in: Waas, Bernd/Van Voss, Guus Heerma (eds.), Restatement of Labour Law in Europe. Volume I: The Concept of Employee, Oxford 2017, 1-21 (14); Rosioru, European Labour Law Journal 2014/5(3-4), 285.

42. For the group of workers working on the basis of an employment contract, this article uses the term 'employees'.

43. Based on the Eurostat database (own calculations).

44. Eurostat, Self-employment statistics 2018, own calculations.

45. Senčur Peček, Darja/Franca, Valentina, 'From student work to false self-employment: how to combat precarious work in Slovenia?' in: Kenner, Jeff/Florczak, Izabela/Otto, Marta (eds.) Precarious work: the challenge for labour law in Europe. Cheltenham/Northampton 2019, 119.

46. Official Gazette of the Republic of Slovenia, No. 21/13 of 13 March 2013.

47. 213(2) ZDR-1. 
labour protection, at the end of each year the EDS must notify the client on whom he or she is economically dependent about the conditions under which he or she operates, by providing all evidence and information necessary to assess the existence of economic dependence. These administrative hurdles lead to a low rate of actual uptake.

An EDS is granted limited labour law protection and the following provisions of ZDR-1 apply to the them: (i) the prohibition of discrimination, (ii) the minimum period of notice, (iii) the prohibition of termination of the employment contract on the grounds of unfounded dismissal (including absence from work due to parental leave pursuant to the regulations on parenthood) and (iv) the provisions on liability for damages. ${ }^{48}$ In addition, ZDR-1 provides income security to the EDS to some extent, since it states that the remuneration for the contractually agreed work should reflect the nature, scope and quality of the work undertaken, taking into account the collective agreement and the general legal acts that are binding on the client, as well as the obligations to pay taxes and contributions. Although the EDS are not entitled to all employment protection rights as enshrined in ZDR-1 (only those listed above), like all self-employed, they are fully covered by parental insurance. They are therefore entitled to leave associated with parenthood (maternity, paternity, and parental leave), as explained in detail below.

In the Slovenian social security system, all groups of the self-employed have the same legal status and are subject to compulsory insurance in all four existing social insurance schemes (pension and disability insurance, health insurance, unemployment insurance, and parental insurance) and consequently have to pay social security contributions at least from the minimum insurance base. ${ }^{49}$ Their social security status is therefore comparable to that of employees (working on the basis of an employment contract), and they are in principle entitled to all rights. However, there are still some problematic (de iure and de facto) aspects of the various social insurance schemes that reduce their social security. ${ }^{50}$

It must be emphasised that although the extension of (limited) labour protection to the EDS in Slovenia can be considered appropriate, most EDS do not enforce this status. Although they meet all the criteria, they often do not inform the client of their economic dependence. Consequently, this means that they do not enjoy (limited) labour protection. As there is no case law regarding the EDS many questions remain unanswered. In its transitional and final provisions, the ZDR-1 states that the Articles on EDS (Articles 213 and 214) will only apply until the entry into force of the Act on Work and Protection of Economically Dependent Persons (Article 223). However, since 2013, no discussion or further steps have been taken to adapt this Act.

\section{Legal recognition of the economically dependent self-employed in Austria}

While Slovenian law sets out a clear definition of the EDS, in Austria, there is no such general category. The law recognises economic dependency in an 'employee-like' status (Arbeitnehmerähnlichkeit), which is included in the scope of certain labour law Acts. The category is similar to the EDS as it falls

48. 214 (2) ZDR-1.

49. The minimum insurance base is $60 \%$ of the average wage in Slovenia. In May 2021, this amounted to EUR 1,113.72 per month. At a rate of $38.20 \%$, this means that the self-employed must pay at least EUR 425.43 in social security contributions per month.

50. See Rataj, Primož/Bagari, Sara, 'Modern Forms of Work: The Slovenian Perspective', in: Bellomo, Stefano/Ferraro, Fabrizio (eds), Modern forms of work: a European comparative study, Rome 2020, 19-37. 
between the ideal types of employment and self-employment ${ }^{51}$ and is found to be more comparable to the former than the latter. ${ }^{52}$ Certain labour protection Acts define and include in their scope persons who are not employees but who are considered employee-like due to their economic dependence (wirtschaftliche Unselbstständigkeit). ${ }^{53}$ These are the Equal Treatment Act, the Labour and Social Courts Act, the Personnel Leasing Act, the Employee Liability Act, the Federal Highway Toll Act and the Act on the Employment of Disabled Persons. ${ }^{54}$ Lacking explicit inclusion, other important protective regulations, such as the laws regarding working hours, paid holidays - and importantly for this study - maternity protection and parental leave, are not applied to employee-like working relations. ${ }^{55}$

The criteria for employee-likeness have been substantiated by scholarship and case law and include: ${ }^{56}$ the lack of one's own working resources, materials and employees; personal work performance; dependence on the earnings from the contractual relationship for a living; or restrictions on working for other parties. ${ }^{57}$ Other than in Slovenia, economic dependence might exist when there is not only one ${ }^{58}$ but a few major clients. ${ }^{59}$ Another difference is that there is no specific income quota that one must receive from the work in question. The qualification of being employeelike must be considered separately for each working relationship a person engages in. Therefore, a person can be self-employed in one, and employee-like in another working relationship. Take, for example, a lawyer who runs her own law firm and teaches a course at the university, where she is integrated into the university's work organisation, uses the university's working materials and performs her duties personally. She is self-employed as a lawyer but is employee-like in her relationship with the university.

Besides the traditional employment and services contract (self-employment), the Austrian system recognises the free-service contract (freier Dienstvertrag), which can be seen as a hybrid between the two poles. ${ }^{60}$ To those providing their services for a certain amount of time under a

51. Rebhahn in Neumayr/Reissner, ZellKomm ${ }^{3}, \S 1151$ ABGB (1.1.2018, rdb.at) para 7.

52. OGH 21.01.1987 14 ObA 10/87, 'Arbeitnehmerähnliche Personen sind rechtlich selbständig, wirtschaftlich aber unselbständig und stehen deshalb einem Arbeitnehmer näher als einem Unternehmer'.

53. Risak/Rebhahn in Waas/Van Voss 2017, 14.

54. $\S 1$ Abs 3 Z2; $\S 16$ Abs 3 Z2 GlBG; § 51 Abs 3 Z2 Arbeits- und Sozialgerichtsgesetz (ASVG); 3 Abs 4

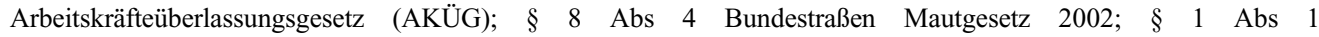
Dienstnehmerhaftpflichtgesetz; § 7a Behinderteneinstellungsgesetz.

55. Risak/Rebhahn in Waas/Van Voss 2017, 20.

56. RS0050835: 4Ob180/54; 7Ob221/56; 4Ob106/55; 4Ob162/54; 1Ob171/56; 2b638/56; 7Ob289/57; 8Ob248/62; 8Ob64/ 67; 6Ob307/69; 6Ob65/72; 4Ob592/72; 4Ob80/74; 6Ob8/75 (6Ob9/75); 4Ob20/75; 3Ob108/75; 4Ob558/76; 4Ob92/76; 4Ob75/78; 4Ob43/80; 6Ob566/83; 14ObA10/87; 4Ob223/99v

57. Not all the criteria need to be met cumulatively; further see Neumay in Neumayr/Reissner, ZellKomm ${ }^{3} \S 51$ ASGG, Arbeitgeber- und nehmerbegriff (Stand 1.1.2018, rdb.at) para 20 with reference to case law: OGH 18.9.1962, $1 \mathrm{Ob}$ 264/62; OGH 17.7.1963, 1 Ob 166/63; OGH 9.7.1980, 1 Ob 591/80.

58. Kietaibl, Christoph, 'Zur Ausnahme der "leitenden Angestellten" aus dem Arbeitszeitrecht', in: Kietaibl, Christoph/ Schörghofer, Felix/Schrammel, Walter (eds.), Rechtswissenschaft und Rechtskunde: liber amicorum für Robert Rebhahn, Vienna 2014, 35-43 (39).

59. RS0086121, Für die Frage der Arbeitnehmerähnlichkeit ist entscheidend das Merkmal der wirtschaftlichen Unselbständigkeit und daher die Abhängigkeit von einem oder mehreren bestimmten, nicht aber von einer unbegrenzten, ständig wechselnden Anzahl von Unternehmern.

60. Sabara, Bettina, 'Arbeitsrechtliche Aspekte des freien Dienstvertrags', in: Aktuelles Recht zum Dienstverhältnis 2016/ 6493 (4), https://lesen.lexisnexis.at/_/arbeitsrechtliche-aspekte-des-freien-dienstvertrages/artikel/ard/2016/6493/ARD_ 2016_6493_004.html (last visited 10 June 2021), 1. 
so-called 'freier Dienstvertrag', only some of the rights to which employees are entitled apply. According to Brameshuber, they might be termed 'semi-dependent'. ${ }^{61}$

There is no mention of this category of workers in the Civil Code, however, over the years, criteria have been developed by the courts to differentiate them from employees. These workers perform their work personally but are not personally dependent according to the law. The lack of personal subordination rules out the possibility of an employment contract. ${ }^{62}$ Still, employment rights provided for in the Civil Code apply to them analogously as far as they are not based on the person's personal dependence. The relevant Articles are those relating to an entitlement to reasonable, adequate wages, termination periods and modalities of termination in case of termination by giving notice, and grounds for premature termination for substantive reasons. ${ }^{63}$ The provision of 16 weeks of maternity leave according to the Maternity Protection Act applies only to those who are defined as free service contract workers who fall according to social security law. ${ }^{64}$

Roughly speaking, free service contract workers comprise two groups: typical entrepreneurs who offer their services on the market to different contracting parties, and atypical self-employed workers who do not permanently appear on the market and/or only work for one or a few major clients. ${ }^{65}$ Members of the former group are considered to be traditionally self-employed and must insure themselves in accordance with the Commercial Social Security Act. ${ }^{66}$ For example, a therapist will enter into free service contracts with her patients/clients. She will own her own practice and set her own schedule, will still most likely be an entrepreneur, but one who engages in (personal) services rather than production.

The latter group are employee-like workers with a free service contract. ${ }^{67}$ This is not a specific type of contract, 'but rather a typological concept' ${ }^{68}$ The criteria are similar to the general definition of employee-likeness, but in addition to the aforementioned criteria, a free service contract is required. ${ }^{69}$ In contrast with other self-employed persons, they are included in the General Social Security Act. ${ }^{70}$ This distinction is particularly relevant to our research question, as the Maternity Protection Act, which generally grants rights to employed mothers only, extends its protection to employee-like workers with a free service contract by reference to their inclusion into the General Social Security Act. ${ }^{71}$

61. Brameshuber, Elisabeth, 'The "personal work relationship” in Austria', European Labour Law Journal, 2019/10(3), 187-197 (189).

62. Rebhahn in Neumayr/Reissner, ZellKomm ${ }^{3}, \S 1151$ ABGB (1.1.2018, rdb.at) para 2.

63. $§ 1152 ; \S \S 1159-1159 \mathrm{~b} ; \S \S 1162-1162 \mathrm{~d}$ ABGB, for more detail see Brameshuber, European Labour Law Journal, 2019/ $10(3), 194$.

64. See $\S 1$ (5) and $\S \S 3,5$ (1) and 3 Maternity Protection Act: Mutterschutzgesetz 1979 (MSchG), BGB1 221/1979 and $\S 4$ Abs 4 General Social Security Act: Allgemeines Sozialversicherungsgesetz (ASVG), BGB1 189/1955.

65. Rebhahn in Neumayr/Reissner, ZellKomm ${ }^{3}, \S 1151$ ABGB (1.1.2018, rdb.at) para 127.

66. Commercial Insurance Act: Gewerbliches Sozialversicherungsgesetz (GSVG), BGB1 560/1978.

67. E.g. language teachers recognised as employee-like freelancers: OLG Wien 24.3.2000, 9 Ra 292/99y, similar OGH 23.3.2010, 8 ObA 57/09d; contrarily: OGH 26.6.1997, 8 Ob A 2158/96b.

68. Brameshuber, European Labour Law Journal 2019/10(3), 190.

69. Further, only such contracts that are in the commercial realm of the client are included in the ASVG; if the contract is in the private realm, employee-like freelancers are not included in the ASVG but need to insure themselves through the GSVG, like the self-employed; Kietaibl in Kietaibl/Schörghofer/Schrammel 2014, 40.

70. $§ 4$ (4) ASVG.

71. $\S 1(5)$ and $\S \S 3,5$ (1) and 3 MSchG $m V a \S 4$ Abs 4 ASVG. 


\section{The need for parental protection in the light of economic dependence}

In most legal systems, a distinction is made between maternity protection and parental leave, with the former only being granted to mothers. Maternity protection generally aims to improve health and safety protection for pregnant workers and those who have recently given birth. ${ }^{72}$ It follows social as well as health protection purposes. At the European level, the Directive on Maternity Protection prescribes 14 weeks of maternity leave, two of which are compulsory. ${ }^{73}$ The scope is limited to employees. Measures such as the ban on exposure to dangerous activities and substances clearly have health protection purposes. The protection against termination of employment, on the other hand, reacts primarily not to the physical condition of the mother but her economic vulnerability. These rights are generally limited to employees, as they respond to the risks typically associated with the employment relationship and personal dependence.

In addition, Directive 2010/41/EU on the application of the principle of equal treatment between men and women engaged in an activity in a self-employed capacity prescribes measures to ensure that female self-employed workers and the female partners of the self-employed may be granted sufficient maternity benefits enabling interruptions in their occupational activity for at least 14 weeks. Article 18 states that 'the economic and physical vulnerability of pregnant self-employed workers makes it necessary for them to be granted the right to maternity benefits.' The European Parliament consistently called on the Commission to boost maternity protection for self-employed women, linking the Directive's purpose of equal treatment to the availability of maternity protection. ${ }^{74}$ Explicit reference is made not only to their physical, but also to their economic, vulnerability. ${ }^{75}$

As the protective purpose of some labour law regulations is not the personal but the economic dependency of workers, ${ }^{76}$ the (partial) exclusion of the EDS from these areas is questionable. The EDS tend to be economically vulnerable due to their dependency on one major client; this vulnerability becomes particularly apparent during pregnancy. ${ }^{77}$ It is not only personal instructions that can induce female employees to expose themselves to risks to their pregnancy during work; this might also result from economic constraints that force self-employed women to expose themselves to health risks, for example, through an increased workload and the 'waiving' of breaks. The responsibility for health protection rests solely on the worker, who has to weigh it up against her own economic and professional interests. Of course, this responsibility comes with autonomy, which is a key feature of self-employment. However, this argument fails to precisely recognise

72. Council Directive 92/85/EEC of 19 October 1992 on the introduction of measures to encourage improvements in the health and safety at work of pregnant workers and workers who have recently given birth or are breastfeeding (tenth individual Directive within the meaning of Article 16 (1) of Directive 89/391/EEC).

73. Article 8 of the Council Directive 92/85/EEC of 19 October 1992 on the introduction of measures to encourage improvements in the health and safety at work of pregnant workers and workers who have recently given birth or are breastfeeding (tenth individual Directive within the meaning of Article 16 (1) of Directive 89/391/EEC)

74. Directive 2010/41/EU of the European Parliament and of the Council of 7 July 2010 on the application of the principle of equal treatment between men and women engaged in an activity in a self-employed capacity and repealing Council Directive 86/613/EEC, recital 4.

75. Directive 2010/41/EU of the European Parliament and of the Council of 7 July 2010 on the application of the principle of equal treatment between men and women engaged in an activity in a self-employed capacity and repealing Council Directive 86/613/EEC, recital 18.

76. Kietaibl in Kietaibl/Schörghofer/Schrammel 2014, 41.

77. Thomasberger Martina in Burger-Ehrnhofer, Karin; Schrittwieser, Bettina; Thomasberger, Martina, Mutterschutzgesetz und Väter-Karenzgesetz, $\S \S 1,2 \mathrm{MSchG}$, para 43. 
those constraints that do not lie in the personal but the economic dependency of the self-employed. The fear of losing their one major client increases the pressure for the EDS. From this point of view, also excluding the EDS from health protection measures, such as the ban on exposure to dangerous activities and substances, is highly questionable. For the EDS, the risk of losing their one main client due to pregnancy-related work interruptions de facto amounts to a termination, but without the accorded protection.

Besides the immediate risks relating to pregnancy and birth, childcare responsibilities also pose social challenges. As a result, parental protection rights in respect of the reconciliation of paid and unpaid work are granted to all working parents, regardless of their gender. ${ }^{78}$ At the European level these rights have recently been revisited through the work-life balance Directive. ${ }^{79}$ As these rights ensure women's participation in the workforce and promote the equal distribution of care work, they function not only as labour protection rights but also as equal treatment measures. ${ }^{80}$ The new Directive grants two months of non-transferable parental leave to each parent to encourage fathers, in particular, to take their share. ${ }^{81}$ It further includes ten days of voluntary paternal leave. ${ }^{82}$ Reacting to the 'growing flexibilisation of the labour market', ${ }^{83}$ the work-life balance Directive grants its rights to non-standard workers, such as part-time workers, fixed-term contract workers and temporary agency workers. However, this is not sufficient as 'an increasing number of workers, such as those on zero-hours contracts, those self-employed or involved in the "platform economy", as well as domestic workers, trainees and volunteers ${ }^{84}$ might still be excluded.

While employees have the right to parental leave periods, the self-employed are expected to manage their time independently. This is especially difficult for the EDS. While it might be argued that the self-employed determine their own working hours, it cannot be overlooked that the 'loss' of working hours due to childcare responsibilities is not merely a question of rearranging a work schedule. If one has to shoulder the unpaid care work for a family, it is very unlikely that there will be enough hours left in the day to 'independently' earn a living.

On the social security of parents, and most importantly an entitlement to benefits, research shows that where maternity/paternity schemes are insurance-based, the self-employed generally are mandatorily insured and therefore eligible. However, they often face de facto problems due to different eligibility criteria and receive lower benefits. ${ }^{85}$

78. For an in-depth analysis of the extension of parental rights since the 1980s, see Sagmeister, Maria, Geschlechtergerechte Arbeitsteilung. Der arbeitsrechtliche Schutz von Eltern zwischen Zwang und Autonomie, Vienna 2021, Chapter 5.

79. Directive (EU) 2019/1158 of the European Parliament and of the Council of 20 June 2019 on work-life balance for parents and carers and repealing Council Directive 2010/18/EU.

80. See Sagmeister, Maria, 'Autonomy and Equality in the Context of Parental Labour Rights. A Legal Gender Studies Approach to Mandatory Parental Leave Policies', University of Vienna Law Review, 2019/3, https://oi.org/10. 25365/vlr-2019-3-1-93.

81. Directive (EU) 2019/1158 of the European Parliament and of the Council of 20 June 2019 on work-life balance for parents and carers and repealing Council Directive 2010/18/EU, recital 20.

82. Directive (EU) 2019/1158 of the European Parliament and of the Council of 20 June 2019 on work-life balance for parents and carers and repealing Council Directive 2010/18/EU.

83. Chieregato, International Journal of Comparative Labour Law and Industrial Relations 2020/36(I), 13.

84. Chieregato, International Journal of Comparative Labour Law and Industrial Relations 2020/36(I), 12.

85. Spasova et al., Access to social protection 2017, 35, 48. 


\section{Parental protection in Slovenia and Austria: differences between employees and the EDS}

This section provides a comparison of the national legislations in search for a rationale for possible solutions. It approaches the question of what scope of parental labour law and social protection is, and should be, granted to the EDS. After providing a broader overview of parental protection legislation in both countries, the comparison focuses on the most important areas of parental protection: (1) protection against unlawful dismissal, (2) health protection, (3) parenthood-related leave, and (4) benefits and allowances.

Parental protection in Slovenian legislation can be divided into two groups of rights. The first group consists of rights deriving from the employment relationship on the basis of the ZDR-1. ${ }^{86}$ Their goal is providing employment protection to employees due to, and during, pregnancy and parenthood. Except for the above-mentioned limited labour law protection that is granted to the EDS if they invoke their status, the self-employed are not entitled to these rights. The second group comprises rights derived from the parental insurance and family benefits schemes, both regulated in the Parental Protection and Family Benefits (Zakon o starševskem varstvu in družinskih prejemkih; ZSDP-1). ${ }^{87}$ As all the self-employed are subject to compulsory insurance in all four existing social insurance schemes, including parental insurance, they are entitled to all rights deriving from parental insurance scheme, including: maternity, paternity and parental leave, the right to compensation benefits during this leave, the right to work part-time due to parenthood and the payment of social security contributions for this, the payment of social security contributions in the case of ceasing work due to caring responsibilities for four or more children, the right to compensation during a breastfeeding break and payment of social security contributions during a breastfeeding break. The same applies to the rights to health services required for the purpose of pregnancy, preparation for childbirth, childbirth and postnatal care that are guaranteed in the compulsory health insurance. Family benefits are granted to all parents, regardless of their employment status.

Parental protection rights in Austria are regulated in a number of different Acts. Regarding labour protection rights, the Maternity Protection Act (Mutterschutzgesetz, MSchG) ${ }^{88}$ grants maternity leave and parental leave to female employees. Parental leave for fathers and co-mothers is regulated by the Paternity Leave Act (Väter-Karenzgesetz, VKG), ${ }^{89}$ which grants a short period of birth-related leave as well as parental leave to employees only. These Acts also include protection against dismissal. While female employee-like freelancers are partially included in the MSchG, which grants them maternity leave, freelancers and self-employed individuals are generally not entitled to this under the VKG. ${ }^{90}$ A short period of birth-related leave is available to them under the Family Time Bonus Act (Familienzeitbonusgesetz, FamZeitbG). ${ }^{91}$

86. See Kresal, Barbara/Zbyszewska, Ania, 'Through Work-Life-Family Reconciliation to Gender Equality? Slovenia and the United Kingdom's Legal Frameworks Compared', in: De Groof, Sarah/Hendrickx, Frank/ Blanpain, Roger et al. (eds.), Work-Life Balance in the Modern Workplace, Interdisciplinary Perspectives from Work-Family Research, Law and Policy, Bulletin of Comparative Labour Relations 2017/98.

87. Official Gazette of the Republic of Slovenia, No. 26/14 of 14 April 2014; For a detailed insight into the Slovenian social security system, see Kresal, Barbara/Kresal Šoltes, Katarina/Strban, Grega, Social Security Law in Slovenia, Kluwer Law International; 4th edition, 2020.

88. Maternity Protection Act: Mutterschutzgesetz 1979 (MSchG), BGB1 221/1979.

89. Paternal Leave Act: Väter-Karenzgesetz (VKG), BGB1 651/1989.

90. $§ 1$ Abs 5 MSchG (ex contrario); § 1 Abs 1 VKG, Wolfsgruber-Ecker in Neumayr/Reissner (eds.), ZellKomm ${ }^{3}, \S 2$ VKG (1.1.2018, rdb.at) para 4.

91. Family Time Bonus Act: Familienzeitbonusgesetz (FamZeitbG), BGB1 53/2016. 
In respect of social security rights, the Parental Benefit Act (Kinderbetreuungsgeldgesetz, $\mathrm{KBGG})^{92}$ applies to all parents, independent of any previous self-employed or salaried employment, requiring only that any gainful employment is suspended for the period of entitlement. Maternity benefits (Wochengeld) are regulated separately under the two Social Security Acts, the General Social Security Act for employees ${ }^{93}$ and the Commercial Social Security Act for the self-employed. $^{94}$

\section{Protection against unlawful dismissal}

Self-employed parents often do not take up (full) leave or even delay family formation due to the fear of losing their main client. ${ }^{95}$ This risk is comparable to the fear of losing one's job due to a lack of protection against dismissal. In the early days of maternity protection, that is, during industrialisation, workers often did not take the leave they were entitled to after childbirth, as they would have not been able to return due to a lack of protection against dismissal. ${ }^{96}$ The risk of the termination of their main business relationship is higher for the EDS than for other types of self-employed persons who can rely on several clients for their income sources. Therefore, protection against unlawful dismissal is one of the key elements when discussing the scope of parental protection that should be enjoyed by the EDS.

The Slovenian regulation (ZDR-1), which defines the limited scope of labour protection that should be granted to the EDS, includes the prohibition of termination on the grounds of unlawful dismissal. Absence from work due to parental leave is considered such an unlawful reason. As already mentioned, this regulation is not effective in practice because many of the EDS do not enforce their status. Furthermore, the EDS are not entitled to the special protection from dismissal that pregnant women and parents enjoy. This special form of additional protection prohibits an employer from terminating the employment contract with an employee during the period of pregnancy and breastfeeding, as well as during the period of uninterrupted parental leave and for one month after the end of such leave. This protection does not fall within the scope of limited labour law protection that is granted to the EDS. This means that the major client might terminate the contract of service during the pregnancy of an EDS, as long as it is not on the unlawful reason of her being pregnant. Therefore, if an EDS has enforced their status, the contract can only be terminated if there is a valid reason for such termination, e.g., a business reason.

Furthermore, in contrast with the employees, the self-employed are not entitled to the right return to the same job and to benefit from any improvement in working conditions to which they would have been entitled during absence due to parental leave. ${ }^{97}$

92. Parental Benefit Act: Kinderbetreuungsgeldgesetz (KBGG), BGB1 I 103/2001.

93. $\$ 157$ ASVG.

94. § 102a GSVG.

95. On the impact the form of work has on the decision to start a family see Domadenik et al. in Kresal Šltes/Strban/ Domadenik 2020, 276.

96. Hausen, Karin 'Arbeiterinnenschutz, Mutterschutz und gesetzliche Krankenversicherung im Deutschen Kaiserreich und in der Weimarer Republik. Zur Funktion von Arbeits- und Sozialrecht für die Normierung und Stabilisierung der Geschlechterverhältnisse', in: Gerhard, Ute (eds.), Frauen in der Geschichte des Rechts, Munich 1997, 713-743 (732-733).

97. Parental leave is used in ZDR-1 as an umbrella term for all three forms of leave: maternity, paternity and parental leave. In this regard, see Article 15, 16 of Directive 2006/54/EC on the implementation of the principle of equal opportunities and equal treatment of men and women in matters of employment and occupation. 
In Austria, employees who give birth are subject to the Maternity Protection Act (MSchG) and are therefore entitled to 16 weeks of maternity leave. ${ }^{98}$ They are protected against dismissal from the beginning of the pregnancy until four months after the end of their maternity or additional parental leave. Other employed parents are entitled to parental leave, during which time they, too, are protected against dismissal. Similar to the Slovenian special protection, in Austria employed parents cannot be dismissed during this period, without good reason. Just like in Slovenia, the EDS are not included into this strong protective frame in general.

In addition, female employee-like freelancers were partially included in the scope of the Maternity Protection Act in 2016. ${ }^{99}$ The obligation to notify the employer of the pregnancy applies. ${ }^{100}$ Regrettably, the protection against dismissal has not been extended to them. In the case of the termination of their contract in light of knowledge of the pregnancy or up to four months after childbirth, they can challenge the termination on the grounds of the Equal Treatment Act. ${ }^{101}$ If necessary, the freelancer must make the reason for termination on the grounds of the pregnancy plausible; she can also accept the termination and claim compensation, ${ }^{102}$ possibly in addition to damages due to discrimination according to the Equal Treatment Act. As the initiative lies with the worker and she must make the reason for termination plausible, this form of dismissal protection is weaker than the special protection of the Maternity Protection Act, where a court must consent to the termination beforehand.

Providing the EDS with protection against unlawful dismissal on the grounds of pregnancy and parenthood is necessary to guarantee job security. This is important, as many self-employed indicate that the manner in which they perform their work influences their decision to start a family, mainly because of the lack of job security. ${ }^{103}$ It could be assumed that this is particularly true for the EDS. Furthermore, the lack of protection in this area limits the EDS with regard to other parental protection rights, as they must fear losing their client while enjoying parental benefits or leave. In effect, this could influence their decision not to have (more) children.

However, the question of how they can ensure their contractual position remains open. Protection against unlawful dismissal enjoyed by employees does not appear suitable as the legal basis for work differs, therefore, adjustments must be made to ensure that the solution is effective in practice. For example, a contract of service or a free service contract concluded between an EDS and their main client for a fixed period should be prolonged for the period of a parenthood-related leave. In contrast, a contract concluded for an indefinite period should be protected against termination by the client during pregnancy and parenthood-related leave without good reason.

\section{Health protection}

Birth-related health protection is one of the most essential aspects of parental protection rights for workers who are pregnant, have recently given birth or are breastfeeding. Therefore, it should be

98. $\S 3$ para $1, \S 5$ para $1 \mathrm{MSchG}$.

99. $\S 1(5)$ and $\S \S 3,5(1)$ and $3 \mathrm{MSchG}$

100. $\S 3$ (4) MSchG.

101. Enzelsberger, Julia, Gesetzliche Neuerungen im arbeitsrechtlichen Elternschutz. Änderungen im MSchG, VKG und AngG seit 1. 1. 2016 in Kraft, Zeitschrift für Arbeits- und Sozialrecht (ZAS) 2016/12, 67-72 (68).

102. § $1162 \mathrm{~b}$ ABGB.

103. Domadenik et al. in Kresal Šoltes/Strban/Domadenik 2020, 276. 
granted to all working mothers or rather parents who give birth, ${ }^{104}$ notwithstanding their employment status. Health protection purposes are met by an entitlement to maternity leave and the ban on certain dangerous working activities. Both are granted to employees in Slovenia under the ZDR-1 and in Austria under the MSchG.

In Slovenia, the prohibition against carrying out specific working tasks and working overtime or at night applies only to employed mothers during pregnancy and the breastfeeding period if the risk assessment of such work indicates a risk to her or the child's health. Contrarily, the right to maternity leave, which starts 28 days before giving birth and then lasts for 77 days after giving birth and includes compensation benefits during the leave (100\% of the previous income), derives from the parental insurance scheme, which also covers the self-employed. Parents are entitled to parental insurance rights if they are insured on the basis of self-employment, employment or another equivalent status. This means that (besides employed mothers) self-employed mothers, including the EDS, are also entitled to maternity leave and are therefore protected from work-related health risks during these 105 days.

However, regarding the ban on certain dangerous working activities, they are not protected. It applies only to employees, while the self-employed are obliged to take care of their own health and safety at work.

As mentioned above, in Austria, employed mothers, as well as employee-like mothers with a free service contract, ${ }^{105}$ are entitled to 16 weeks of maternity leave. ${ }^{106}$ The whole period is compulsory; therefore, it is neither subject to the mother's discretion nor that of the employer/ client. ${ }^{107}$ Self-employed women can report their business as being dormant for the period during which they are receiving maternity benefits.

Similar to Slovenia, in Austria certain potentially health-threatening activities are also banned for pregnant employees as well as employees who have recently given birth or are breastfeeding. While health-threatening activities and materials after childbirth are prohibited for employee-like freelancers as well, those before are not. It is difficult to understand why the prenatal bans were not extended. These provisions protect women from having to do heavy physical work or handling dangerous substances that could endanger their pregnancy. It is also highly regrettable, in the light of health protection, that protection against dismissal has not been extended to freelancers during their maternity leave, as health protection is only then effectively granted if workers do not need to fear losing their job while on leave, or

104. Surrogate mothers and transgender persons giving birth challenge the legal definition of motherhood. These phenomena not only raise the question of how to include new forms of motherhood in the existing legal frame but also highlight the necessity of redefining parenthood with regard to changing notions of gender. Also, concerning the health protection aspects, it would be more appropriate to simply target the circumstances of pregnancy and birth, regardless of a person's gender, see Sagmeister, Maria, 'Mutterschutz, Papa-Monat und heteronormative Familienorganisation', Zeitschrift GENDER 2019/3, 116-131.

105. $\S 1(5)$ and $\S \S 3,5(1)$ and $3 \mathrm{MSchG}$

106. $\S 3$ para $1, \S 5$ para $1 \mathrm{MSchG}$.

107. In Austria, the entire 16 weeks of leave are compulsory; in other legal systems, only a smaller amount is compulsory, while the vast part of the leave is an entitlement. For example, in , maternity leave amounts to 105 calendar days, of which only 15 days are compulsory. The European Directive on maternity protection prescribes an entitlement to 14 weeks of leave, of which two weeks are mandatory; further, it is up to the discretion of the Member States to implement longer periods. Article 8 of the Council Directive 92/85/EEC of 19 October 1992 mentions the introduction of measures to encourage improvements in the health and safety at work of pregnant workers and workers who have recently given birth or are breastfeeding (tenth individual Directive within the meaning of Article 16 (1) of Directive 89/391/EEC. 
losing their main client when choosing to arrange for their working conditions in a way that accommodates their health best during pregnancy.

\section{Parental and paternity leave}

Maternity leave serves not only health protection but also childcare purposes. Regarding the second purpose, additional parental leave for both parents is granted by the law.

In Slovenia, all types of leave (maternity, paternity and parental leave) are regulated in the ZSDP-1, which includes employees as well as the self-employed. In Austria, on the other hand, the Maternity Protection Act regulates parental leave for mothers, while fathers and co-mothers rely on the (much more recent) Paternity Leave Act. In addition to parental leave, fathers and co-mothers have a statutory entitlement to one month of birth-related leave immediately following childbirth (colloquially referred to 'Ddaddy's month'). ${ }^{108}$ They are also protected against dismissal during this period. ${ }^{109}$ Parental leave, as well as the Daddy's month, is available to employees only, whereas maternity leave is granted also to employee-like mothers who work on basis of a free service contract. Free service contracting fathers and co-mothers have a birth-related leave opportunity somewhat comparable to the 'Daddy's month' on the basis of the Family Time Bonus Act. However, it is not an entitlement, but depends on an agreement between the worker and the contract partner, which can be refused without giving reason.

The exclusion of the self-employed from working time regulations is justified, as the selfemployed manage their time independently and might have employees of their own on whom they can rely. For the EDS, on the other hand, the lack of entitlement to parental leave, or more specifically, the protection against dismissal during this period, might result in their inability to make use of their parental benefits, as they cannot afford to put their working relationships on hold due to the fear of losing their main client. The characteristic of parental leave, as a period of time during which one is not held responsible for neglecting one's working duties, particularly in the sense of protection from dismissal, might be best adapted for the EDS in terms of protection from contractual termination during the period in which they receive parental benefits.

\section{Benefits and allowances}

The EDS are entitled to maternity as well as childcare benefits in both countries. Legal frameworks which finance cash benefits in the case of maternity, paternity or, more generally, parenthood as an insurance case from contributions or from the state budget can be described as beneficial regarding the support of EDS parents. In countries where these rights arise from employment (and are co-financed by employers), this may mean that the self-employed have no, or limited entitlement.

Accordingly, even though all self-employed persons are covered by parental insurance in Slovenia and thus formally have access to the corresponding benefit, they are typically entitled to limited benefits because they often insure themselves at the minimum insurance base. ${ }^{110}$ This means that they are entitled to substantially lower compensation benefits (starševsko nadomestilo),

108. § 1a VKG, this entitlement was introduced in 2019: Bundesgesetz mit dem das Väter-Karenzgesetz und das Landarbeitsgesetz 1984 geändert werden, BGB1 73/2019 (Novella to the Paternal Leave Act 2019).

109. § 1a para 6 VKG.

110. In 2016, almost $70 \%$ of self-employed persons in Slovenia paid social security contributions on the minimum insurance base for pensions, according to the European Commission (European Commission, The 2018 Pension Adequacy 
which are calculated on the basis from which the social security contributions have been paid. The same goes for the compensation benefits during maternity, paternity and parental leave, ${ }^{111}$ as the basis for the calculation of compensation benefits is the average basis from which the social security contributions have been paid in the twelve months preceding the first application for the compensation benefit. Unlike in Austria, there is no flat-rate model available.

Regarding the eligibility for these rights, the conditions applied to the self-employed are equal to the conditions that apply to employees. To be entitled to compensation benefits during maternity (105 days), paternity (30 days) and parental (130 days granted to each parent) leave, no qualifying period is required. The worker (employed or self-employed) has to be insured according to the ZSDP-1 prior to the beginning of the leave. In this case, they are entitled to maternity, paternity or parental leave and granted the compensation benefit during the period of leave. Even if a person is not entitled to leave because they are not insured the day before the first day of their leave, they are entitled to compensation benefit if they have been insured for parental protection for at least 12 months within the last three years. Similar to Austria, while on leave and receiving compensation benefit, their business must be dormant. If parents are not insured (or have not been for at least 12 months within the last three years) and are therefore not entitled to compensation benefit, they are entitled to parental allowance (starševski dodatek), financed from the state budget. Parental allowance lasts for 365 days following the birth of a child (or longer in the case of twins, etc.) and is paid in a lump sum in the amount of approximately EUR 400 per month.

In Austria, one must differentiate between maternity benefit (Wochengeld) and parental benefits (Kinderbetreuungsgeld). During the 16 weeks of compulsory maternity leave, ${ }^{112}$ employed mothers receive $100 \%$ of their average income within the last three months, on the basis of the General Social Security Act. ${ }^{113}$ The costs of medical care and hospitalisation are also covered. Fully insured self-employed women receive maternity benefits on the basis of the Commercial Social Security Act, in addition to the coverage of medical care costs and hospitalisation. ${ }^{114}$ Since 2013, the business can also be reported as dormant. ${ }^{115}$ Unlike in Slovenia, the allowance for self-employed mothers can take two forms: the provision of an assistant who takes on the operational work of the pregnant woman so that her self-employed activity can continue to run without interruption, or as a lump sum cash benefit of around EUR 50 per day. However, for the EDS, who typically do not run traditional businesses, the cash benefit is more suitable.

If a mother is not entitled to maternity benefit, she can receive the parental benefit from childbirth onwards. Parental benefits are granted to all parents with no regard to their employment status, as long as certain earning limits are not exceeded while receiving the allowance. ${ }^{116}$

Report: current and future income adequacy in old age in the EU, Country profiles, Volume II, Joint Report prepared by the Social Protection Committee (SPC) and the European Commission (DG EMPL), Luxembourg 2018, 234).

111. The same applies to the other benefits, which are also calculated on the basis from which the social security contributions have been paid, for example, unemployment benefit, sickness benefit and pensions.

112. $\S 3$ para $1, \S 5$ para $1 \mathrm{MSchG}$.

113. $\S 162$ ASVG.

114. § 102a GSVG.

115. Marat, Mutterschutzgesetz Kommentar, Vienna 2016, 9.

116. § 2 (1) (3) KBGG. There are two models of parental benefits to choose from: the flat-rate and the income-related model. Within the flat-rate model, parents can choose between a shorter period with higher payments, or a longer period of smaller payments. As the allowance aims to support the parent who cares for the child full-time, it does not allow employment above the marginal earnings threshold (EUR 16,200 per year) for the flat-rate model or a higher individual limit of $60 \%$ of the past year's earnings. If the calculated individual limit amount is higher than EUR 16,200 per year, 
The self-employed face problems in respect of the definition of their earning limits, which often leads to much administrative effort and, in the worst-case scenario, to an obligation to repay the allowance. If the additional earnings limits are not adhered to, a subsequent reclaim is to be expected. As the actual limit calculation for self-employed earnings is quite complicated, particularly the individual earning limit, this often leads to unexpected high reclaims. ${ }^{117}$ Persons who earn a (total) income below the marginal earnings threshold (Geringfügigkeitsgrenze, EUR 460.66 per month in 2021) are exempted from all mandatory insurances, meaning that they are not entitled to rights deriving from those insurances. If they have voluntary self-insurance, ${ }^{118}$ they receive a fixed amount of EUR 9.12 per day as maternity benefit and medical costs.

While all self-employed parents are entitled to either parental allowances or benefits, they face practical problems in both countries.

\section{Conclusion}

To ensure adequate enjoyment of parental protection rights for the EDS, their legal recognition is crucial. The main problem in Slovenia is that to obtain EDS status, one has to notify one's status to the employer and enforce it. This (too) often results in the fact that the self-employed do not enforce this status and are therefore not entitled to limited labour law protection, although de facto, economic dependence still exists. The advantage of the Austrian system lies in the possibility of adapting labour and social protection systems to fit the specifics of different groups of self-employed persons. However, it is questionable whether the current Austrian legislation adequately takes into account the needs of all groups that can be defined as EDS, given the low level of labour protection enjoyed by individual groups. Further, as Brameshuber suggests, 'the existence of the intermediate category' of the free service contract and, more particularly, the economically dependent and therefore employee-like free service contract workers and their partial inclusion into employment rights, hinders a wider discussion of the criteria defining the employment relationship. ${ }^{119}$

This has also been pointed out, beyond the Austrian case, by the European Economic and Social Committee ${ }^{120}$ and Rosioru: ${ }^{121}$ While, on one hand, the undeniable advantage of creating intermediate levels of protection for certain professional categories lies in the (limited) social security and labour law rights conferred to members of these intermediate groups, protective rules may be distorted, and persons who traditionally within the scope of labour law can find themselves excluded and/or reclassified into the intermediate categories.

the parent can earn this correspondingly higher annual additional income during the entire reference period of the flat-rate benefit. For the income-related model, the limit for extra earnings is set at EUR 7,300 (§ 24 Abs 1 Z 3 KBGG). During the 'Daddy's month', parents may apply for a maximum 'family time bonus' of EUR 700, ${ }^{[16]}$ which will be deducted from their later parental benefit allowance; $\S 2$ para 7 KBGG amended in 2016 in the course of the introduction of the Family Time Bonus Act, BGB1 53/2016.

117. Oswald, Günther, ,Wenn Selbstständige tausende Euro Kindergeld zurückzahlen müssen', derstandard.at 26.11.2018, www.derstandard.at/story/2000092102048 (last accessed 10 June 2021). A complaint regarding the question of whether the level of complexity might be unconstitutional was denied by the Constitutional Court in 2009, VfGH 26.02.2009, G128/08 ua, Slg 18705.

118. A reduced rate is available to them in accordance with $\S 19$ a ASVG.

119. Brameshuber, European Labour Law Journal 2019/10(3), 196.

120. Opinion of the European Economic and Social Committee (2011).

121. Rosioru, European Labour Law Journal 2014/5(3-4), 305. 
In Austria as well as in Slovenia, the EDS are included in social rights frameworks but widely excluded from labour rights. Although the differences between employment and self-employment regarding their autonomy in structuring their work schedule justify the focus of labour protection rights on employees, these prototypical categories do not reflect the reality of the EDS. Further, social and labour rights cannot be analysed completely separately, as insurance-based entitlements often vary depending on the employment status. Social and labour rights correlate; without social security, people are reluctant to make use of their labour rights and vice versa. This is particularly true in respect of the protection against dismissal, as, for example, the historical development of maternity protection shows, whereas the early leave regulations were not effective due to the risk of losing one's job. ${ }^{122}$

As has been argued with regard to specific fields of labour law, such as the entitlement to paid holidays or the right to collective bargaining, the social protection of the economically weaker party is one of the main goals of labour law. ${ }^{123}$ The risks which lie in being the weaker party become particularly apparent during pregnancy and parenthood. ${ }^{124}$ As women carry the burdens of unpaid care work disproportionally, this is also an equal treatment issue. Therefore, different parental protection rights need to be adjusted to fit diverse working arrangements and ensure protection when needed.

The main challenge remains what scope of labour and social protection should be granted to the EDS. From a social security perspective, they are exposed to similar traditional social risks to dependent workers; ${ }^{125}$ this includes parenthood. Consequently, they need the same protection and should be equally covered. Furthermore, social risk is nothing other than the risk of losing one's economic security, as social security is a public mechanism of providing income security when social risks materialise, or of preventing them. This implies that social security should be granted equally to all economically active persons in need of social protection. However, some differences may still occur due to the nature of the circumstances in which the work is performed, which in itself does not justify a difference in the scope of rights but calls for an adapted way of exercising them. In this regard, we agree with authors who suggest that social security systems should be neutral in terms of employment status, but sufficiently specific in implementing the rules with regard to the different forms of work and occupational groups they cover. ${ }^{126}$

Since, in the case of the EDS, the main feature of the dependent employment relationship, i.e. personal subordination, does not exist, we can conclude that there is no need for full protection under labour law. Regarding traditional self-employment, the lack of personal subordination translates to the fact that they determine their own working hours and conditions, that they do not need to fear dismissal, and therefore are not in need of entitlement to parental leave and protection from

122. Hausen in Gerhard 1997, 732-733.

123. Brameshuber, European Labour Law Journal, 2019/10(3), 197.

124. Thomasberger in Burger-Ehrnhofer/Schrittwieser/Thomasberger, Mutterschutzgesetz und Väter-Karenzgesetz, $\S \S 1,2$ MSchG, para 43.

125. Traditional social security risks are enshrined in ILO Convention No. 102 on minimum social security standards (1952). For example, they, too, can get sick, get old, become parents and as a result, they are left without income or their costs increase.

126. See Schoukens, Paul, 'Comparison of the social security law for self-employed persons in the Member-States of the European Union', in: European Institute of Social Security, Changing Work Patterns and Social Security (European Institute of Social Security Yearbook 1999), Antwerpen 2000. 
dismissal. While this might be true for the traditional self-employed, it overlooks how people in new forms of self-employment face problems similar to employees.

To start with, deficits regarding decent work should be addressed in all forms of employment relationships. ${ }^{127}$ But even further, the need for (some) labour protection for the EDS cannot be disputed, although it is not based on personal but economic dependence. In this regard, we have shown that protection against dismissal, particularly during periods of absence due to parental leave, and health protection during pregnancy and breastfeeding form the minimum standard of parental protection in labour law which should be granted to all workers notwithstanding their employment status. Although they are formally independent in their working decisions, their decisions (also regarding family) are de facto strongly influenced by the relationship with their main client. The constraints the EDS face due to their economic dependence result in a limitation of their autonomy, which needs to be countered through labour law instruments.

Coming back to our research question of the scope of parental protection that should be granted to the EDS, we can conclude that some protection is already in place, but it is insufficient and no longer fully reflects the organisation of different forms of work. Social security and (at least a limited scope of) labour protection should be granted equally to all economically active persons, thus also, or nowadays, particularly, to the EDS. As pointed out several times by the Slovenian Constitutional Court, the legislator must respond to the changes occurring in society by adopting appropriate legislation, which is even more true when those changes affect human rights and fundamental freedoms. This is required by the principle of adapting the law to social conditions, which is one of the principles of the rule of law. ${ }^{128}$ In this respect, changes are necessary both in the area of labour and social security law, as their purpose is to secure the existence and free development of each individual in the constantly changing social relations of the workplace.

\section{Author's Note}

Sara Bagari, Department of Labour Law and Social Security Law, Faculty of Law, University of Ljubljana; contact: sara.bagari@pf.uni-lj.si

\section{Declaration of Conflicting Interests}

The author(s) declared no potential conflicts of interest with respect to the research, authorship, and/or publication of this article.

\section{Funding}

The author(s) disclosed receipt of the following financial support for the research, authorship, and/or publication of this article: This work was supported by the Österreichischen Akademie der Wissenschaften (grant number Post-DocTrack-Programm / 85075).

\section{ORCID ID}

Maria Sagmeister (D) https://orcid.org/0000-0003-4457-6311

127. Williams/Lapeyre, Dependent self-employment 2017, 36.

128. Decisions of the Constitutional Court of the Republic of Slovenia in cases: U-I-69/03 from 20 October 2005, U-I-186/ 12 from 14 March 2013 and U-I-146/12 from 14 November 2013. Strban/Bagari, Przegląd Prawa i Administracji Tom 123 (2020), 92. 